[Letter]

\title{
Decomposition of Tristearin by Ozonolysis over Heterogeneous Catalyst under Moderate Condition
}

\author{
Kaori Kunisawa, Kohei Urasaki, Yumi Otsu, Shigeru Kato, Toshinori Kojima, and \\ Shigeo Satokawa \\ Department of Materials and Life Science, Faculty of Science and Technology, Seikei University, \\ 3-3-1 Kichijyoji-kitamachi, Musashino, Tokyo 180-8633, JAPAN
}

(Received March 11, 2008)

\begin{abstract}
Ozonolysis of triacylglycerol was carried out over heterogeneous catalysts. The triacylglycerol was decomposed to some compounds with low boiling points containing hydrocarbons, aldehydes, ketones, fatty acids and lactones over H-Y zeolite catalyst at 353-423 K. The amounts of products were strongly dependent on the properties of catalysts and reaction conditions.
\end{abstract}

\section{Keywords}

Biodiesel fuel, Ozonolysis, Tristearin, Zeolite catalyst

Vegetable oils have become alternative energy sources for production of transportation fuels from viewpoint of greenhouse gas emission control and depletion of fossil fuel resources. Generally, biodiesel fuel as an alternative transportation fuel has been produced by transesterification of vegetable oils, animal fats or waste cooking oils with methanol. Fatty acid methyl esters are formed by the transesterification of triacylglycerol (TG) with methanol. The methylesterification of TG can improve the viscosity and volatility of raw oils ${ }^{1), 2}$.

One of the problems of the transesterification process is the use of a homogeneous strong alkali catalyst, such as a sodium hydroxide or a potassium hydroxide. This process requires a large amount of washing water to remove an alkali catalyst in the products. Moreover, equivalent amount of glycerol with TG was produced as a by-product.

Many improvement methods have been developed for the conventional transesterification process $^{3)-5)}$. Development of heterogeneous catalysts is one of the effective approaches to improve the conventional biodiesel fuel production methods. Direct catalytic cracking of vegetable oils, animal fats or recycled cooking greases over solid catalysts has been examined to produce the new transportation fuels. However, this method requires high temperature (623-723 K), hydrogen addition and initial high pressure $(1-3 \mathrm{MPa})^{6)-8)}$.

Ozonolysis of oils is simple and easy method for biodiesel production. Some researchers have reported the ozonolysis of oils ${ }^{9)}$, fatty acid methyl esters $^{10)}$ and fatty acids ${ }^{11), 12)}$ to upgrade the products. The chemical compositions of the products were only oxygen containing compounds such as aldehydes and carbonic acids.

We have already reported the evidence for hydrocarbon production by ozonolysis of fish waste

\footnotetext{
“温和な条件下に扔ける不均一系触媒を用いたトリステアリンのオゾンによる分解”

國澤 香織里、浦崎 浩平、大津 裕美、加藤 茂、小島 紀德、里川 重夫

成蹊大学理工学部物質生命理工学科

T 180-0083 東京都武蔵野市吉祥寺北町 3-3-1

*Corresponding author, E-mail: satokawa@st.seikei.ac.jp
} 
oil $^{13)}$ and palm oil ${ }^{14)}$ over heterogeneous catalysts. If hydrocarbon-rich products are formed by the ozonolysis of vegetable oils, it is preferable to obtain new type of biodiesel fuel. However, the chemical compositions of the products, the effects of catalysts and the reaction pathways of ozonolysis of oils were not clear.

The object of this study is to investigate the effects of catalysts on ozonolysis of glycerol tristearate (tristearin) which was composed of liner saturated fatty acids and does not contain carbon-carbon double bond in its structure over heterogeneous catalysts to obtain hydrocarbon-rich products under moderate conditions. Generally, natural vegetable oils are consisted of several types of saturated and unsaturated fatty acids. If the natural vegetable oils are used as raw materials for ozonolysis reaction, it is too hard to investigate the decomposed products and their reaction pathways. Therefore, tristearin was used as raw oil in this study.

Several types of zeolites (mordenite, $\mathrm{Y}$ and beta), metal oxides $\left(\mathrm{Al}_{2} \mathrm{O}_{3}, \mathrm{SiO}_{2}-\mathrm{Al}_{2} \mathrm{O}_{3}, \mathrm{MgO}\right.$ and $\left.\mathrm{CeO}_{2}\right)$ and ion-exchange resin (Amberlyst 15) were used as solid catalysts for the ozonolysis of tristearin. Zeolites and some metal oxides were supplied by the Catalysis Society of Japan. Tristearin (Tokyo Chemical Industry Co., Ltd.; $50 \mathrm{~g}$ ) was put into a stainless steel tube reactor $(24.5 \mathrm{~mm} \Phi \times 200 \mathrm{~mm}$

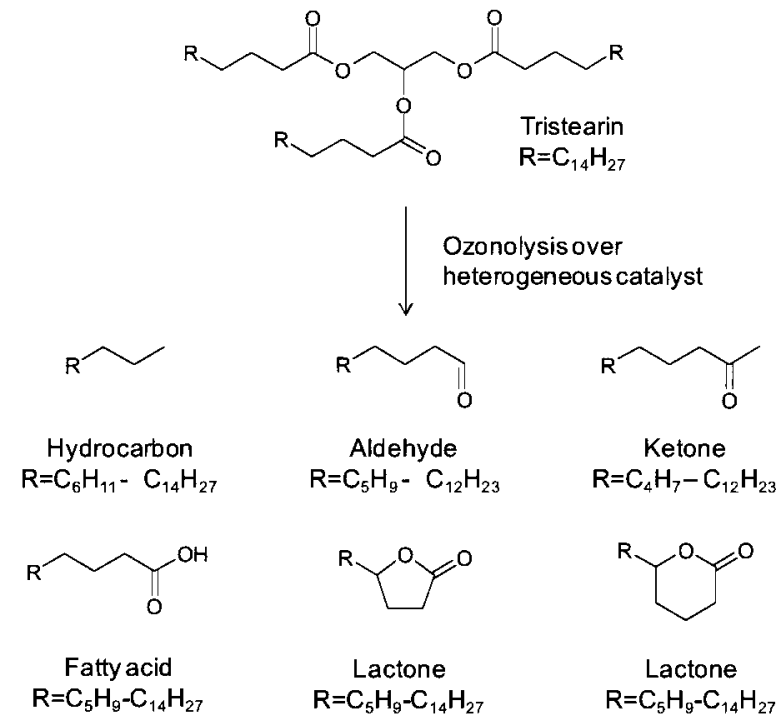

Fig. 1 Decomposed Products by Ozonolysis of Tristearin
Table 1 Contents of Decomposed Products over Various Catalysts by Ozonolysis of Tristearin at 353 $\mathrm{K}$ for $4 \mathrm{~h}$

\begin{tabular}{|c|c|c|c|c|c|}
\hline \multirow[t]{2}{*}{ Gas } & \multirow[t]{2}{*}{ Catalyst } & \multicolumn{4}{|c|}{ Contents $[\%]$} \\
\hline & & $\overline{\mathrm{HCs}^{\text {a) }}}$ & Others $^{b)}$ & DGs & TGs \\
\hline \multirow[t]{12}{*}{$\mathrm{O}_{3}$} & H-mordenite & 0.2 & 0.9 & 4.7 & 94.2 \\
\hline & Na-mordenite & 0.2 & 0.2 & 1.4 & 98.2 \\
\hline & H-beta & 1.3 & 18.9 & 14.1 & 65.7 \\
\hline & HY5.3 & 1.5 & 8.4 & 13.6 & 76.5 \\
\hline & HY5.5 & 0.1 & 0.0 & 0.4 & 99.4 \\
\hline & $\mathrm{SiO}_{2}-\mathrm{Al}_{2} \mathrm{O}_{3}$ & 0.1 & 0.0 & 0.4 & 99.5 \\
\hline & $\mathrm{Al}_{2} \mathrm{O}_{3}$ & 0.4 & 14.1 & 13.9 & 71.6 \\
\hline & $\mathrm{MgO}$ & 0.1 & 0.0 & 0.6 & 99.3 \\
\hline & $\mathrm{CeO}_{2}$ & 0.6 & 11.9 & 10.9 & 76.5 \\
\hline & $\mathrm{La}_{2} \mathrm{O}_{3}$ & 0.3 & 7.4 & 9.1 & 83.3 \\
\hline & Ion exchange resin & 0.2 & 7.3 & 10.4 & 82.1 \\
\hline & None & 0.1 & 0.4 & 1.4 & 98.1 \\
\hline $\mathrm{O}_{2}$ & H-beta & 0.0 & 0.0 & 0.0 & 100.0 \\
\hline- & H-beta & 0.0 & 0.0 & 0.0 & 100.0 \\
\hline 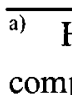 & is, b) & xyg & & $\mathrm{ng}$ & rgan \\
\hline
\end{tabular}

$\mathrm{L})$ and melted at $333 \mathrm{~K}$. Catalyst $(1 \mathrm{~g})$ was put into the reactor without any pretreatment. The mixture was mechanically stirred and ozone gas (2000-3000 $\mathrm{ppm}$ in oxygen; $0.5 \mathrm{~L} \cdot \mathrm{min}^{-1}$ ) was supplied from bottom of the reactor through $50 \mu \mathrm{m}$ of suction filter to make small bubbles. The ozonolysis was carried out at $353-433 \mathrm{~K}$ for $4-16 \mathrm{~h}(0.1 \mathrm{MPa})$. The chemical compositions and of products were analyzed by a gas chromatography-mass spectrometry (GC-MS: QP2010 Plus, SHIMADZU, $\mathrm{m} / \mathrm{z}:$ 40-1090).

Figure 1 shows the compounds of the decomposed products by the ozonolysis of tristearin over H-beta zeolite (JRC-Z-B25: $\mathrm{SiO}_{2} / \mathrm{Al}_{2} \mathrm{O}_{3}<25$, $\mathrm{Na}=c a .0 .15 \mathrm{wt} \%)$ at $353 \mathrm{~K}$ for $4 \mathrm{~h}$. Many compounds with low boiling points containing hydrocarbons, aldehydes, ketones, fatty acids and lactones were obtained accompanied by un-reacted TGs and some intermediates, including diacylglycerols (DGs) and monoacylglycerol (MG). On the other hand, tristearin was little decomposed under the following conditions: the absence of catalysts at $353 \mathrm{~K}$ for $4 \mathrm{~h}$ and only oxygen without ozone over H-beta zeolite. These results indicate that the decomposition of tristearin should be 
promoted by the synergistic effect with the zeolite catalyst and ozone.

Table 1 lists the contents of the products which were calculated by the relative peak areas in the total ion chromatogram of the GC-MS. The contents of the decomposed products varied with the catalysts. With regard to the hydrocarbon production from tristearin, $\mathrm{H}$-beta and HY5.3 (JRC-Z-HY5.3: $\mathrm{SiO}_{2} / \mathrm{Al}_{2} \mathrm{O}_{3}=5.31, \mathrm{Na}_{2} \mathrm{O}=1.1$ $\mathrm{wt} \%$ ) were superior to the other catalysts. The content of hydrocarbons in the product decomposed over HY5.3 was slightly higher than that in the product decomposed over H-beta. The content of hydrocarbons in the product decomposed over HY5.5 zeolite (JRC-Z-HY5.5: $\mathrm{SiO}_{2} / \mathrm{Al}_{2} \mathrm{O}_{3}=5.6$, $\mathrm{Na}_{2} \mathrm{O}=4.3 \mathrm{wt} \%$ ) was much lower than that in the product decomposed over HY5.3. It is interesting that the catalytic activities in the ozonolysis of tristearin over two H-Y type zeolites were significantly different with each other. While $\mathrm{SiO}_{2} / \mathrm{Al}_{2} \mathrm{O}_{3}$ ratios of $\mathrm{HY} 5.3$ and $\mathrm{HY} 5.5$ was almost same, the content of $\mathrm{Na}_{2} \mathrm{O}$ in HY5.5 (4.3 wt\%) was quite higher than that in HY5.3 (1.1 wt\%). That is to say, $\mathrm{H}^{+}$exchange ratio of HY5.5 is much lower than that of HY5.3. Therefore, the low activity over HY5.5 for the decomposition of tristearin may be caused by its low $\mathrm{H}^{+}$exchange ratio in HY5.5. On the other hand, H-mordenite (JRC-Z-HM20: $\left.\mathrm{SiO}_{2} / \mathrm{Al}_{2} \mathrm{O}_{3}=18.3, \quad \mathrm{Na}_{2} \mathrm{O}=0.04 \mathrm{wt} \%\right)$ and Na-mordenite (JRC-Z-M15: $\mathrm{SiO}_{2} / \mathrm{Al}_{2} \mathrm{O}_{3}=15.0$, $\mathrm{Na}_{2} \mathrm{O}=5.9$ wt $\%$ ) were not effective for the decomposition of tristearin. Therefore, it is considered that the activity and the selectivity for the hydrocarbon production by the decomposition of tristearin dependent on the $\mathrm{H}^{+}$exchange ratio and zeolite structure types. $\mathrm{SiO}_{2}-\mathrm{Al}_{2} \mathrm{O}_{3}$ (JRC-SAH1: $\mathrm{SiO}_{2} / \mathrm{Al}_{2} \mathrm{O}_{3}=4.0, \mathrm{Na}_{2} \mathrm{O}=0.013 \mathrm{wt} \%$ ) was also not effective for the decomposition of tristearin. The catalytic activities for the decomposition of tristearin over $\mathrm{Al}_{2} \mathrm{O}_{3}$ (JRC-ALO6: $\mathrm{Na}_{2} \mathrm{O}<0.0015$ $\mathrm{wt} \%), \mathrm{CeO}_{2}$ (JRC-CEO1) and Amberlyst 15 were almost same as that over HY5.3. On the other hand, the hydrocarbon selectivity over these metal oxides and ion-exchange resin were lower than that over HY5.3.

Effects of temperature and reaction time were investigated by using HY5.3. Figure 2 shows the

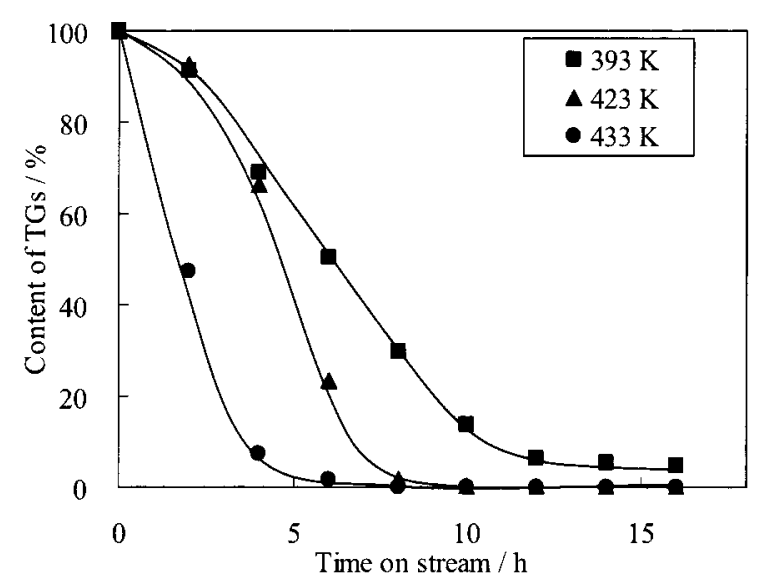

Fig. 2 Time Course Changes in Content of Non-reacted Tristearin by Ozonolysis over HY5.3

Table 2 Contents of Liquid Products by Ozonolysis of Tristearin over HY5.3

\begin{tabular}{lccc}
\hline & \multicolumn{3}{c}{ Contents [wt\%] } \\
\cline { 2 - 4 } & Product-A & Product-B & Product-C \\
\hline Hydrocarbons & 11.0 & 10.8 & 2.5 \\
Fatty acids & 40.2 & 35.8 & 40.1 \\
Aldehydes & 2.6 & 3.7 & 3.1 \\
Ketones & 6.7 & 7.3 & 8.1 \\
Lactones & 12.9 & 14.6 & 15.5 \\
Others & 26.5 & 27.8 & 30.5 \\
\hline
\end{tabular}

changes in content of non-reacted tristearin in the products after decomposition of tristearin at $393 \mathrm{~K}$, $423 \mathrm{~K}$ and $433 \mathrm{~K}$. When the reaction temperature increased, the contents of non-reacted tristearin decreased. Tristearin was completely decomposed after the reaction at $423 \mathrm{~K}$ for $10 \mathrm{~h}$ and $433 \mathrm{~K}$ for 6 $\mathrm{h}$, and the decomposed products changed from solid phase to liquid phase at room temperature. However, tristearin was not decomposed completely under low temperature condition at $393 \mathrm{~K}$.

Contents of hydrocarbons in the liquid products obtained by the ozonolysis of tristearin over HY5.3 at $393 \mathrm{~K}$ for $16 \mathrm{~h}$ (hereafter described as product-A), at $423 \mathrm{~K}$ for $10 \mathrm{~h}$ (hereafter described as product-B) and $433 \mathrm{~K}$ for $6 \mathrm{~h}$ (hereafter described as product-C) were determined by using a gas chromatography with flame ionization detection (GC-2010, SHIMADZU). Table 2 shows the contents of hydrocarbons, fatty acids, aldehydes, ketones and lactones in these liquid products. The 
contents of hydrocarbons in these liquid products in the products- $\mathrm{A},-\mathrm{B}$ and $-\mathrm{C}$ were $11.0,10.8$ and 2.5 $\mathrm{wt} \%$, respectively. While the decomposition rate of tristearin increased with in the increase of reaction temperature, hydrocarbon content in the product-C obtained at $433 \mathrm{~K}$ was rather lower than those in products- $\mathrm{A}$ and $-\mathrm{B}$.

The contents of lactones in the products-A, -B and $-\mathrm{C}$ were $12.9,14.6$ and $15.5 \mathrm{wt} \%$, respectively. These lactones were consisted of $\gamma$ - and $\delta$-alkyl lactones. The lactones can be expected to be useful chemical raw materials and new oxygenate fuel additives ${ }^{15), 16)}$. On the other hand, the contents of fatty acids were much higher than those of hydrocarbons and lactones. The production of glycerol was also detected slightly in the liquid products.

Gas phase products which were obtained after ozonolysis experiments of $6 \mathrm{~h}$ with the use of HY5.3 at $393 \mathrm{~K}$ were analyzed by using a gas chromatography with thermal conductivity detector (GC-8A, SHIMADZU). Carbon dioxide (0.5 vol\%) was detected in the outlet gas from the ozonolysis reactor. At the present time, we consider that the formation of carbon dioxide is due to the decomposition of products $(\mathrm{C} n$; where $n=$ carbon number) to give other products with lower carbon number $(\mathrm{C} n-m$; where $m=<n)$.

The following main conclusions can be derived from the results of the present work. Hydrocarbons and some oxygen containing organic compounds were produced by ozonolysis of tristearin over heterogeneous catalyst. The contents of products were strongly depended on the properties of catalysts. Tristearin was completely decomposed by ozonolysis over HY5.3 and the decomposed products were liquefied at room temperature. We consider that the ozonolysis of vegetable oils over heterogeneous catalyst can be expected to be the effective method as new alternative biodiesel fuel production by increasing the yield of hydrocarbons (and lactones). And we have been developing new heterogeneous catalysts and optimizing the reaction conditions. On the other hand, the reaction pathway of ozonolysis of tristearin is much complicated due to formation of many kinds of chemical compounds. Now we have been studying to make clear of this reaction pathway.

\section{Acknowledgement}

This study was supported by the New Energy and Industrial Technology Development Organization (NEDO, Japan).

\section{References}

1) Feedman, B., Pryde, E. H., Mounts, T. L., $J$. Am. Oil Chem. Soc., 61, 1638 (1984).

2) Shay, E. G., Biomass \& Bioenergy, 4, 227 (1993).

3) Zhang, Y., Dubé, M. A., McLean, D. D., Kates, M., Bioresouece Thecnology, 89, 1 (2003).

4) Gerpen, J. V., Fuel Processing Thechnology, 86, 1097 (2005).

5) Kulkarni, M. G., Dalai, A. K., Ind. Eng. Chem. Res., 45, 2901 (2006).

6) Charusiri, W., Vitidsant, T., Energy and Fuels, 19, 1783 (2005).

7) Twaiq, F. A., Zabidi, N. A. M., Bhatia, S., Ind. Eng. Chem. Res., 38, 3230 (1999).

8) Snåre, M., Kubicková, I., Mäki-Arvela, P., Eränen, K., Murzin, D. Y., Ind. Eng. Chem. Res., 45, 5708 (2006).

9) Sorino, N. U. Jr., Migo, V. P., Matsumura, M., $J$. Am. Oil Chem. Soc., 80, 997 (2003).

10) Nishikawa, N., Yamada, K., Matsutani, S., Higo, M., Kigawa, H., Inagaki, T., J. Am. Oil Chem. Soc., 72, 735 (1995).

11) Katrib, Y., Biskos, G., Buseck, P. R., Davidovits, P., Jayne, J. T., Mochida, M., Wise, M. E., Worsnop, D. R., Martin, S. T., J. Phys. Chem. A., 109, 10910 (2005).

12) Zahardis, J., Petrucci, G. A., Atoms. Chem. Phys. Discuss, 6, 11093 (2006).

13) Kato, S., Kunisawa, K., Kojima, T., Murakami, S., J. Chem. Eng. Jpn., 37, 863 (2004).

14) Kunisawa, K., Totoki, Y., Lim, K., Koga, S., Koga, H., Satokawa, S., Kato, S., Kojima, T., Proceedings, 6th APCSEET, (2007).

15) Koseki, K., Ueno, H., Ito, T., Kawabi, K., Jpn. Kokai Tokkyo Koho JP 1997-194856 (1997).

16) Robinson, J., M., U. S. Pat. 052985 (2006). 